\title{
Short communication: Practical issues in implementing volatile metabolite analysis for identifying mastitis pathogens
}

\author{
Kasper A. Hettinga, ${ }^{* 1}$ Frank A. M. de Bok, $†$ and Theo J. G. M. Lam $\ddagger \S$ \\ *Dairy Science and Technology, Food Quality and Design group, Wageningen University, Bornse Weilanden 9, 6708 WG, Wageningen, \\ the Netherlands \\ tKBBL Wijhe BV, Industrieweg 16, 8131 VZ Wijhe, the Netherlands \\ ¥GD Animal Health, 7400 AA Deventer, the Netherlands \\ §Department of Farm Animal Health, Utrecht University, PO Box 80151, 3508 TD Utrecht, the Netherlands
}

\section{ABSTRACT}

Several parameters for improving volatile metabolite analysis using headspace gas chromatography-mass spectrometry (GC-MS) analysis of volatile metabolites were evaluated in the framework of identification of mastitis-causing pathogens. Previous research showed that the results of such volatile metabolites analysis were comparable with those based on bacteriological culturing. The aim of this study was to evaluate the effect of several method changes on the applicability and potential implementation of this method in practice. The use of a relatively polar column is advantageous, resulting in a faster and less complex chromatographic setup with a higher resolving power yielding higherquality data. Before volatile metabolite analysis is applied, a minimum incubation of $8 \mathrm{~h}$ is advised, as reducing incubation time leads to less reliable pathogen identification. Application of GC-MS remained favorable compared with regular gas chromatography. The complexity and cost of a GC-MS system are such that this limits the application of the method in practice for identification of mastitis-causing pathogens.

Key words: mastitis, metabolites, pathogens, incubation, artificial neural network

\section{Short Communication}

Fast and specific determination of mastitis-causing pathogens is of great interest, both for choice of treatment as well as for herd management decisions to decrease infectious pressure and prevent the spread of mastitis pathogens. Currently, determination of mastitis pathogens is generally done by bacteriological

Received April 17, 2015

Accepted July 10, 2015.

${ }^{1}$ Corresponding author: kasper.hettinga@wur.nl culturing (NMC, 2004) or PCR techniques (Koskinen et al., 2009). Previous research (Hettinga et al., 2008) showed that the results of a method for mastitis pathogen identification based on volatile metabolites analysis (VMA) in milk samples were comparable with bacteriological culturing. The VMA technique for bacterial identification has been used much more broadly than only for mastitis diagnosis (e.g., Bos et al., 2013; Settachaimongkon et al., 2014). Potential advantages of this new method are the reduction in analysis time and in costs of diagnosis.

The method, as it was developed (Hettinga et al., 2008), showed potential drawbacks that may prevent implementation in practice. Attention points include the cooling of the GC column, the incubation time, the necessity of sample fixation after incubation, and the costs of MS. The VMA technique developed previously (Hettinga et al., 2008) relied on the use of liquid $\mathrm{N}$ to cool the GC column for improved separation of volatile components. When using a more polar GC column, this cooling may no longer be necessary (Christie, 1989; McNair and Miller, 2009), although the effect on performance characteristics, such as sensitivity and reproducibility, is unknown. Second, the application of autosamplers in large-scale routine analysis can lead to prolonged storage at ambient temperature, resulting in further fermentation in the sample, and thereby uncontrolled variation in VMA results. A cooled platform or addition of a preservative may be required to fix the samples after a defined incubation period. Third, the minimal incubation time was determined to be 8 h (Hettinga et al., 2009a). That study, however, compared an incubation time of 4 and $8 \mathrm{~h}$, without time points in between, with $8 \mathrm{~h}$ being long enough and 4 $\mathrm{h}$ being too short. To be able to fit the whole analysis into 1 working day, we wanted to know whether $6 \mathrm{~h}$ of incubation would suffice for correct prediction of the pathogen. Fourth, the use of MS makes the developed analysis rather expensive and labor-intensive. The use of regular GC without MS but with flame ionization 
detector (FID) would simplify the analysis, and thus make it cheaper.

The aim of our study was to evaluate the use of a polar GC column, the effect of adding a preservative, using shorter incubation times, and GC-FID on the applicability of the VMA technique for pathogen detection in milk samples, which would all simplify implementation of this method in practice.

\section{Milk Samples}

For optimizing GC and testing the use of a preservative, samples inoculated with mastitis pathogens were used, similar to Hettinga et al. (2009b). Milk from a cow with a continuously low SCC $(<75,000$ cells $/ \mathrm{mL})$ was collected and pasteurized $\left(72^{\circ} \mathrm{C}\right.$ for $\left.15 \mathrm{~min}\right)$. Bacterial strains isolated by GD Animal Health (Deventer, The Netherlands) and stored at $-80^{\circ} \mathrm{C}$ were separately added to brain-heart infusion (BHI) broth (CM0225, Oxoid, Cambridge, UK) and incubated at $37^{\circ} \mathrm{C}$ for 24 h. This broth was used to inoculate milk samples. For comparing GC columns, one sample inoculated with Staphylococcus aureus and incubated for $24 \mathrm{~h}$ was used to induce the formation of many volatile components at relatively high levels. Ten samples $(5 \mathrm{~mL} /$ sample $)$ per pathogen (Staph. aureus, CNS, Streptococcus uberis, Streptococcus dysgalactiae, or Escherichia coli) were prepared for testing the optimized chromatography. To evaluate the need for preservation, a bronopol and sodium azide mixture was added to the samples. A volume of $2.5 \mathrm{~mL}$ of $\mathrm{BHI}$ broth (CM 0225, Oxoid) was mixed with $2.5 \mathrm{~mL}$ of milk to stimulate growth of bacteria. This mix, without the addition of pathogen, was incubated at $37^{\circ} \mathrm{C}$ for $8 \mathrm{~h}$, followed by adding either nothing (control) or a mixture of bronopol (0.01\% wt/ wt, final concentration) combined with sodium azide $(0.02 \% \mathrm{wt} / \mathrm{wt}$, final concentration), after which the sample was incubated for another $24 \mathrm{~h}$ at $20^{\circ} \mathrm{C}$.

For evaluation of incubation time and for comparing GC to GC-MS, milk samples from cows that were sent in for bacteriological mastitis diagnosis were selected from the diagnostic laboratory of GD Animal Health. After taking a sample for culturing, aliquots of approximately $8 \mathrm{~mL}$ were immediately frozen at $-20^{\circ} \mathrm{C}$. Bacteriological culturing was carried out according to National Mastitis Council protocols (NMC, 2004). Only milk samples from which 1 bacterial species was cultured before incubation of the sample were included in the study. The work focused on 3 pathogens (Staph. aureus, Strep. uberis, and Strep. dysgalactiae) of which enough samples per pathogen ( $\mathrm{n}=16$ per pathogen $)$ were available. To evaluate the length of the incubation time, these samples were separated in 2 subsamples and incubated at $37^{\circ} \mathrm{C}$ for 6 and $8 \mathrm{~h}$.

\section{Analysis of Volatile Metabolites}

Five- (inoculated samples) or 1-mL (clinical mastitis samples) milk samples were preheated in $20-\mathrm{mL}$ vials sealed with silicon or Teflon septa and magnetic caps for $1 \mathrm{~min}$ at $60^{\circ} \mathrm{C}$. Volatile metabolites were extracted from the headspace for $5 \mathrm{~min}$ with a $75-\mu \mathrm{m}$ PDMScarboxen SPME fiber (Supelco, Bellefonte, PA) using the combiPAL autosampler (CTC Analytics AG, Zwingen, Switzerland). The volatile metabolites were thermally desorbed from the fiber by heating it in a Best PTV injector (Thermo-Finnigan, San Jose, CA) with an empty liner for $5 \mathrm{~min}$ at $250^{\circ} \mathrm{C}$. The fiber was subsequently cleaned for $10 \mathrm{~min}$ at $290^{\circ} \mathrm{C}$. A vial with $5 \mathrm{~mL}$ of demineralized water was used as blank. Gas chromatography separation of the volatile components was performed on a Finnigan Trace GC gas chromatograph (Thermo-Finnigan) coupled to a Finnigan DSQ mass spectrometer (ThermoFinnigan). Chromatography characteristics were evaluated for 2 different columns: (1) an apolar BPX-5 column of $30 \mathrm{~m}$ in length, $0.15 \mathrm{~mm}$ i.d., and $0.25-\mu \mathrm{m}$ film thickness (SGE, Austin, $\mathrm{TX}$ ), where the oven temperature was held at $-30^{\circ} \mathrm{C}$ for $3 \mathrm{~min}$, raised to $230^{\circ} \mathrm{C}$ at $20^{\circ} \mathrm{C} / \mathrm{min}$, followed by $1 \mathrm{~min}$ of holding; and (2) a polar Stabilwax-DA column of 30 $\mathrm{m}$ in length, $0.32 \mathrm{~mm}$ i.d., and 0.32-mm film thickness (Restek, Bellefonte, PA), where the oven temperature was held at $40^{\circ} \mathrm{C}$ for $2 \mathrm{~min}$, raised to $112^{\circ} \mathrm{C}$ at $14^{\circ} \mathrm{C} /$ min, followed by raising $230^{\circ} \mathrm{C}$ at $20^{\circ} \mathrm{C} / \mathrm{min}$, followed by 3 min of holding. Helium was used as the carrier gas at a flow rate of $0.6(\mathrm{BPX}-5$ column $)$ or $1.8 \mathrm{~mL} / \mathrm{min}$ (Stabilwax-DA column). The MS interface and the ion source were kept at $250^{\circ} \mathrm{C}$. Acquisition was performed in electron impact mode $(70 \mathrm{eV})$ with 2 scans/s; the mass range used was 33 to $250 \mathrm{~m} / z$.

\section{Data Analysis}

The chromatograms were analyzed using the AMDIS software (National Institute of Standards and Technology, Gaithersburg, MD), for improved peak identification. Identification of volatile metabolites was based on matching mass spectra and retention time with pure standards, or comparison to the National Institute of Standards and Technology-Environmental Protection Agency-National Institutes of Health mass spectral database with Kovats indices data from literature (Acree and Arn, 2004). Volatile metabolites that were detected before in mastitis milk samples (Hettinga et al., 2008) were integrated using the XCalibur software package (ThermoFinnigan). The peak area (corrected for blank) in arbitrary units was used for statistical analysis. To emulate the effect of using a regular GC-FID, without MS, the total ion count (TIC) traces were also 
analyzed. NeuralTools (Palisade, Ithaca, NY) was used to develop probabilistic neural networks (PNN), with the conjugate gradient descent method for training. Training of the neural networks was carried out using cross validation, with $70 \%$ ( $\mathrm{n}=33 ; 11$ per pathogen) of the samples used for training and $30 \%(\mathrm{n}=15 ; 5$ per pathogen) for validation.

\section{Optimizing GC}

Two GC columns were evaluated to optimize chromatography of bacterial volatiles. The observed reproducibility of retention time (relative standard deviation $=19$ vs. $57 \%$ ) and peak area (relative standard deviation $=0.9$ vs. $5.4 \%$ ), as well as average signal intensity $\left(1.4 \cdot 10^{8}\right.$ vs. $\left.7.1 \cdot 10^{6}\right)$, were substantially better using the polar Stabilwax-DA versus the apolar BPX-5 column. Moreover, in this way the tedious use of liquid nitrogen cooling, as required for the BPX-5 column, could be omitted. To further test this GC column, inoculated milk samples were used. A PNN was build and tested, which showed a $100 \%$ correct prediction for the pathogen in the test data set, which is higher than the $93 \%$ reported previously (Hettinga et al., 2008). For these reasons, the Stabilwax-DA column was used for all further analyses.

\section{Evaluation of Preservation}

To prevent metabolite formation due to microbial activity after incubation, a bronopol and sodium azide mixture was added to the samples after which they were incubated again. As shown in Figure 1, several additional metabolites were present in the chromatograms of samples that were not preserved (Figure 1B and D) as compared with samples that were preserved (Figure $1 \mathrm{~A}$ and $\mathrm{C}$ ). As these metabolites were similar to those found in mastitis samples, this may reduce prediction accuracy. Thus, these results show the importance of sample fixation after incubation. The postincubation storage period of $24 \mathrm{~h}$ in our experiment is relatively long and may not represent a practical situation. Shorter storage or storage at lower temperature may result in smaller differences. Nevertheless, results shows that postincubation storage can influence the results of VMA and care should be taken with this.

\section{Optimization of Incubation Time and the Use of GC Instead of GC/MS}

Incubation times of 6 and $8 \mathrm{~h}$ were compared to test whether the incubation time could be shortened to $6 \mathrm{~h}$. The VMA data of 3 major pathogens (Staph. aureus, Strep. uberis, and Strep. dysgalactiae) were analyzed

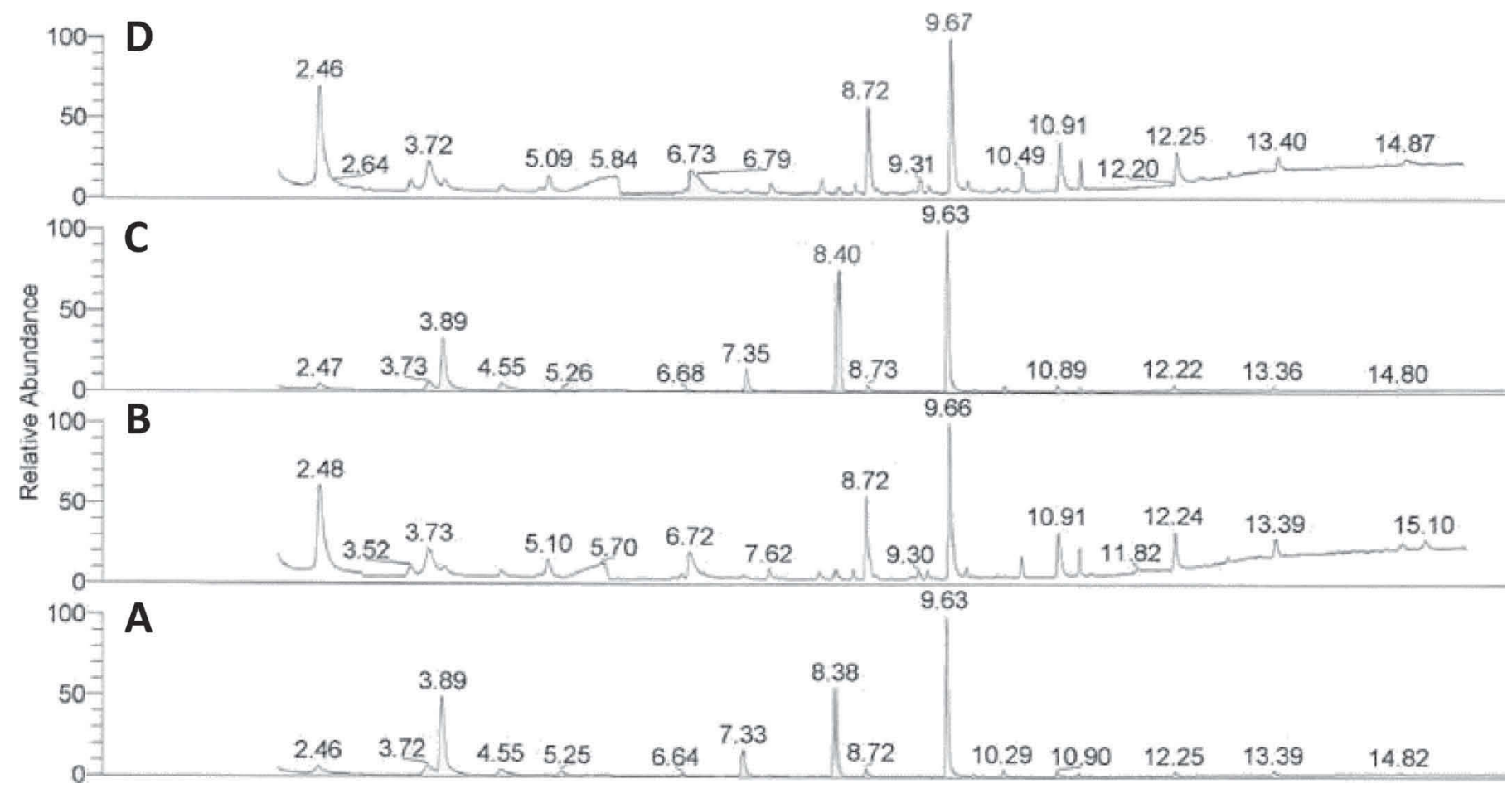

Figure 1. Gas chromatography-mass spectrometry chromatograms of samples with (A and C) and without (B and D) the addition of preservatives. 
Table 1. Cross-validation results of pathogen identification by a probabilistic neural network for mastitis pathogens samples incubated either 6 or $8 \mathrm{~h}$, based on total ion count traces of the GC-MS (to emulate the use of a GC-flame ionization detector)

\begin{tabular}{|c|c|c|c|c|c|c|c|c|}
\hline \multirow{3}{*}{$\begin{array}{l}\text { Microbiological } \\
\text { identification }\end{array}$} & \multicolumn{6}{|c|}{$\begin{array}{l}\text { Predicted by neural network (number of samples identified per } \\
\text { group, } \mathrm{n}=15 \text { per incubation time) }\end{array}$} & & \\
\hline & \multicolumn{2}{|c|}{$\begin{array}{l}\text { Staphylococcus } \\
\quad \text { aureus }\end{array}$} & \multicolumn{2}{|c|}{$\begin{array}{l}\text { Streptococcus } \\
\text { dysgalactiae }\end{array}$} & \multicolumn{2}{|c|}{$\begin{array}{l}\text { Streptococcus } \\
\text { uberis }\end{array}$} & \multicolumn{2}{|c|}{ Correct $(\%)$} \\
\hline & $6 \mathrm{~h}$ & $8 \mathrm{~h}$ & $6 \mathrm{~h}$ & $8 \mathrm{~h}$ & $6 \mathrm{~h}$ & $8 \mathrm{~h}$ & $6 \mathrm{~h}$ & $8 \mathrm{~h}$ \\
\hline Staph. aureus & 4 & 3 & & 1 & 1 & 1 & 80 & 60 \\
\hline Strep. dysgalactiae & 1 & & 3 & 2 & 1 & 3 & 60 & 40 \\
\hline Strep. uberis & & 1 & 2 & & 3 & 4 & 60 & 80 \\
\hline Total correct & & & & & & & 67 & 60 \\
\hline
\end{tabular}

based on the TIC trace of the GC-MS, to emulate the use of a GC-FID instead of a GC-MS. The VMA profiles were analyzed with PNN, showing that incubating for $6 \mathrm{~h}$ gives a slightly higher overall percentage correct predictions compared with $8 \mathrm{~h}$, see Table 1 . The correct prediction rate in both cases, however, was much lower than the $93 \%$ from previous studies (Hettinga et al., 2008), probably due to the fact that GC-FID was emulated without using the detailed data from the mass spectrometer for identification and quantification. Further detailed inspection of the VMA profiles showed that the TIC approach did not allow for separation of compounds with comparable retention times. This may explain the lower identification rate using emulated GC-FID. Reanalyzing the data set based on quantification of the individual mass traces solved the problem of hard to differentiate co-eluting compounds. When this data set was reanalyzed using PNN, 80 and $93 \%$ of the samples were predicted correctly for the samples incubated for 6 and $8 \mathrm{~h}$, respectively, as shown in Table 2. Although the number of pathogens classified in the current study is smaller than in the previous study (Hettinga et al., 2008), the observed identification rate after $8 \mathrm{~h}$ of incubation is supported by results reported previously. These results support our hypothesis that the lower correct prediction rate, as shown in Table 1, may be due to the use of emulated GC. This need to identify and quantify all individual components may also be the reason why Eriksson et al. (2005) were unable to differentiate between pathogens using an electronics nose, because such a device only detects groups of metabolites, not individual metabolites. In addition, it indicates that when the incubation is reduced from 8 to $6 \mathrm{~h}$, less reliable results are obtained. Previous research on identification of pathogens grown in culture broth showed that incubating for 6 to $8 \mathrm{~h}$ is needed (Bruins et al., 2009), which is in the same range as what we found, even though they used a matrix that is more suitable for pathogen growth. A drawback of GCMS over GC-FID is the additional investment required for the MS and additional effort needed for analysis of the more complex data.

\section{Considerations for Application in Practice}

Our results show that headspace analysis is technically feasible, but has several serious drawbacks related to implementation in practice. The additional costs involved in GC-MS analysis would make this method more expensive than regular bacterial culturing or alternative, even faster, techniques such as PCR and matrix-assisted laser desorption/ionization time-of-

Table 2. Cross-validation results of pathogen identification by a probabilistic neural network for mastitis pathogens samples incubated for 6 and $8 \mathrm{~h}$, based on analysis of mass traces of the GC-MS

\begin{tabular}{|c|c|c|c|c|c|c|c|c|}
\hline \multirow{3}{*}{$\begin{array}{l}\text { Microbiological } \\
\text { identification }\end{array}$} & \multicolumn{6}{|c|}{$\begin{array}{l}\text { Predicted by neural network (number of samples identified per } \\
\text { group, } \mathrm{n}=15 \text { per incubation time) }\end{array}$} & & \\
\hline & \multicolumn{2}{|c|}{$\begin{array}{l}\text { Staphylococcus } \\
\text { aureus }\end{array}$} & \multicolumn{2}{|c|}{$\begin{array}{l}\text { Streptococcus } \\
\text { dysgalactiae }\end{array}$} & \multicolumn{2}{|c|}{$\begin{array}{l}\text { Streptococcus } \\
\text { uberis }\end{array}$} & \multicolumn{2}{|c|}{ Correct (\%) } \\
\hline & $6 \mathrm{~h}$ & $8 \mathrm{~h}$ & $6 \mathrm{~h}$ & $8 \mathrm{~h}$ & $6 \mathrm{~h}$ & $8 \mathrm{~h}$ & $6 \mathrm{~h}$ & $8 \mathrm{~h}$ \\
\hline Staph. aureus & 5 & 4 & & 1 & & & 100 & 80 \\
\hline Strep. dysgalactiae & 1 & & 3 & 4 & 1 & & 50 & 100 \\
\hline Strep. uberis & & & 1 & & 4 & 5 & 80 & 100 \\
\hline Total correct & & & & & & & 80 & 93 \\
\hline
\end{tabular}


flight (MALDI-TOF). The use of GC-FID would reduce the cost and complexity of the analysis, but leads to a reduced correct identification rate, as shown in Tables 1 and 2. We therefore concluded that the complexity and cost of a GC-MS system are such that this limits the applicability of VMA for mastitis pathogen identification in practice.

In addition to the studied parameters, also other parameters may be relevant for implementation in practice. In bacteriological mastitis diagnosis, multiple bacteria may occur simultaneously in a single sample. Several preliminary experiments we performed indicate that this may lead to volatile metabolite profiles most similar to the pathogen that grew fastest during incubation (data not shown). This contradicts the findings of de Bok et al. (2011) and Settachaimongkon et al. (2014), who showed that the volatile metabolites of all species grown in a mixed culture could be detected. However, these studies were performed using lactic acid bacteria that grow well together, whereas in a mixed culture of mastitis pathogens usually only 1 pathogen grows well. Samples may have different levels of bacteria, resulting in different optimal incubation times needed. In preliminary data, samples acidified on arrival at the laboratory did not need incubation to show a successful VMA result (data not shown). Also, our study was limited by the sample size, with 16 samples per pathogen and only 3 pathogens in the final experiment, which was due to the specific requirements put on the samples to be included in the study. Further research on these parameters would be needed before final conclusions can be drawn on these aspects.

Overall, the results from our study indicate that the use of a more polar column is advantageous for VMA because it increases the chromatographic resolution and yields higher-quality data. Adding a preservative to the sample after incubation can prevent metabolite production during sample storage between incubation and analysis. Incubation is required for at least $8 \mathrm{~h}$. Use of regular GC instead of GC-MS resulted in lower correct identification rates in our study. The complexity and cost of a GC-MS system are such that this limits the implementation of the VMA method in practice at this point in time.

\section{ACKNOWLEDGMENTS}

We thank Philip Steketee, Sabina Hofmeyer, Vesela Tzeneva, Harrie van den Bijgaart, and Jan Rademaker
(Qlip, Zutphen, the Netherlands), and Kyra Ulfman (GD Animal Health, Deventer, The Netherlands) for their support by performing the GC-MS analyses and discussing the outcomes, as well as Jan Rademaker (Qlip, Zutphen, the Netherlands) for his critical comments on the manuscript. This project was financially support by the province of Gelderland, the Netherlands, and the European Union in the Europees Fonds voor Regionale Ontwikkeling (EFRO) project "Ontwikkeling Vluchtige Metabolietentest voor Koemelk" \#2009013010.

\section{REFERENCES}

Acree, T. E., and H. Arn. 2004. Flavornet and human odor space. Accessed Feb. 27, 2007. http://www.flavornet.org/.

Bos, L. D., P. J. Sterk, and M. J. Schultz. 2013. Volatile metabolites of pathogens: A systematic review. PLoS Pathog. 9:e1003311.

Bruins, M., A. Bos, P. L. Petit, K. Eadie, A. Rog, R. Bos, G. H. van Ramshorst, and A. van Belkum. 2009. Device-independent, realtime identification of bacterial pathogens with a metal oxide-based olfactory sensor. Eur. J. Clin. Microbiol. Infect. Dis. 28:775-780.

Christie, W. W. 1989. Gas chromatography: Theoretical aspects and instrumentation. Pages 43-62 in Gas Chromatography and Lipids: A Practical Guide. Oily Press, Ayr, Scotland.

de Bok, F. A., P. W. Janssen, J. R. Bayjanov, S. Sieuwerts, A. Lommen, J. E. van Hylckama Vlieg, and D. Molenaar. 2011. Volatile compound fingerprinting of mixed-culture fermentations. Appl. Environ. Microbiol. 77:6233-6239.

Eriksson, A., K. Persson Waller, K. Svennersten Sjaunja, J. E. Haugen, F. Lundby, and O. Lind. 2005. Detection of mastitic milk using a gas-sensor array system (electronic nose). Int. Dairy J. 15:1193-1201

Hettinga, K. A., H. J. F. van Valenberg, T. J. G. M. Lam, and A. C. M. van Hooijdonk. 2008. Detection of mastitis pathogens by analysis of volatile bacterial metabolites. J. Dairy Sci. 91:3834-3839.

Hettinga, K. A., H. J. F. van Valenberg, T. J. G. M. Lam, and A. C. M. van Hooijdonk. 2009a. The influence of incubation on the formation of volatile bacterial metabolites in mastitis milk. J. Dairy Sci. 92:4901-4905.

Hettinga, K. A., H. J. F. van Valenberg, T. J. G. M. Lam, and A. C. M. van Hooijdonk. 2009b. The origin of the volatile metabolites found in mastitis milk. Vet. Microbiol. 137:384-387.

Koskinen, M. T., J. Holopainen, S. Pyörälä, P. Bredbacka, A. Pitkälä, H. W. Barkema, R. Bexiga, J. Roberson, L. Sølverød, R. Piccinini, D. Kelton, H. Lehmusto, S. Niskala, and L. Salmikivi. 2009. Analytical specificity and sensitivity of a real-time polymerase chain reaction assay for identification of bovine mastitis pathogens. J. Dairy Sci. 92:952-959.

McNair, H. M., and J. M. Miller. 2009. Basic Gas Chromatography. 2nd ed. Wiley, Hoboken, NJ.

NMC. 2004. Microbiological Procedures for Use in the Diagnostics of Bovine Udder Infection and Determination of Milk Quality. National Mastitis Council, Inc., Madison, WI.

Settachaimongkon, S., M. J. Nout, E. C. Antunes Fernandes, K. A. Hettinga, J. J. M. Vervoort, A. C. M. van Hooijdonk, M. H. Zwietering, E. J. Smid, and H. J. F. van Valenberg. 2014. Influence of different proteolytic strains of Streptococcus thermophilus in coculture with Lactobacillus delbrueckii ssp. bulgaricus on the metabolite profile of set-yoghurt. Int. J. Food Microbiol. 177:29-36. 